\author{
A.A. Bobodzhanov ${ }^{1}$, B.T. Kalimbetov ${ }^{2}$, V.F. Safonov ${ }^{1}$ \\ ${ }^{1}$ National Research University «Moscow Power Engineering Institute», Russia; \\ ${ }^{2}$ Kh.A. Yassawi International Kazakh-Turkish University, Turkestan, Kazakhstan \\ (E-mail:bobojanova@yandex.ru)
}

\title{
Singularly perturbed control problems in the case of the stability of the spectrum of the matrix of an optimal system
}

\begin{abstract}
The paper considers a singularly perturbed control problem with a quadratic quality functional. Such problems in their standard formulation under known spectrum restrictions (the points of the spectrum of the optimal system are not purely imaginary and are located symmetrically with respect to the imaginary axis) were previously considered using the Vasilyeva - Butuzov method of boundary functions. If at least one of the points of the spectrum for some values of the independent variable falls on the imaginary axis, the boundary functions method does not work. It is precisely this situation with the assumption of purely imaginary points of the spectrum that is investigated in this paper. In this case, you have to develop a different approach based on the ideas of the regularization method S.A. Lomov. It should also be noted that in the control problems considered earlier, the cost functional either did not depend on a small parameter at all, or allowed a smooth dependence on the parameter. In this paper, an irregular dependence on a small parameter is allowed, in particular, the presence in them of a rapidly changing damping function in the form of an exponential factor under the integral sign. In this case, the spectrum behavior of the optimal system depends on the damping coefficient, which (under certain conditions) can shift the spectrum in one direction or another in the complex plane. In this case, a situation may arise when some points of the spectrum for individual values (or even on a certain continuum set) of an independent variable can become purely imaginary. This situation is not amenable to investigation by the previously mentioned Vasilieva Butuzov method of boundary functions. However, it can be fully studied using the regularization method S.A. Lomov, the algorithm of which is applied to the considered control problem in the present paper. The presentation of this method begins with a brief description of the maximum principle of L.S. Pontryagin for the classical optimal control problem, which then, along with other ideas, is used to justify the results in the considered control problem.
\end{abstract}

Keywords: singularly perturbed, Pontryagin's maximum principle, regularization, asymptotic convergence.

\section{Introduction}

The presentation of the regularization method of S.A. Lomov [1] begins with a brief description of the Pontryagin's maximum principle for the classical optimal control problem, which is then applied to a linear singularly perturbed control problem with a quadratic quality functional (cost functional) in the case of a stable spectrum of the matrix of an optimal system.

Consider a linear control system

$$
\begin{aligned}
\frac{d x}{d t} & =A(t) x+B(t) u+h(t), x(0)=x^{0} ; \\
J(u) & =\frac{1}{2} \int_{0}^{T}\left(x^{*} Q(t) x+u^{*} R(t) u\right) d t \rightarrow \min ,
\end{aligned}
$$

where $x(t), h(t)$ are $n$ - dimensional; $u(t)$ is $m$ - dimensional vector functions, $x^{0}$ is a constant $n$-dimensional vector; $A(t)$ is $(n \times n)$-matrix; $B(t)$ is $(n \times m)$ - matrix; $Q(t)$ is a symmetric non-negative definite $(n \times n)-$ matrix, $R(t)$ is a symmetric positive definite $(m \times m)$ - matrix, ${ }^{*}$ is a transposition sign. It is required to transfer the system (1) from a given initial position $x(0)=x^{0}$ to a position $x(T)$ in a fixed time $T<+\infty(x(T)$ is not fixed) so that the functional $J(u)$ takes the minimum value. A similar problem was considered in many sources devoted to the theory of optimal control. Our presentation follows the monograph [2]. We introduce a variable 
$x_{0}=x_{0}(t)$, satisfying the equation $\dot{x}_{0}=f_{0}(x, u, t), x\left(t_{0}\right)=0$ (where $f_{0}(x, u, t) \equiv \frac{1}{2}\left(x^{*} Q(t) x+u^{*} R(t) u\right)$ ). Then the problem (1)-(2) will be rewritten as

$$
\begin{aligned}
& \frac{d x_{0}}{d t}=f_{0}(x, u, t), x(0)=0 \\
& \frac{d x}{d t}=A(t) x+B(t) u+h(t), x(0)=x^{0} \\
& x_{0}(T) \rightarrow \min , \quad 0 \leq t \leq T .
\end{aligned}
$$

Denote $f(x, u, t)=\left\{f_{1}, \ldots, f_{n}\right\} \equiv A(t) x+B(t) u+h(t)$ and make Hamiltonian

$$
\begin{aligned}
& \tilde{H}(\psi, x, u, t)=\psi_{0} f_{0}+\sum_{j=1}^{n} \psi_{j} f_{j} \equiv \psi_{0} f+\left(\psi_{1}, \ldots, \psi_{n}\right)\left(\begin{array}{c}
f_{1} \\
\vdots \\
f_{n}
\end{array}\right)= \\
= & \frac{1}{2} \psi_{0}\left(x^{*} Q(t) x\right)+\frac{1}{2} \psi_{0}\left(u^{*} R(t) u\right)+\psi^{*} A(t) x+\psi^{*} B(t) u+\psi^{*} h(t),
\end{aligned}
$$

where $\psi^{*} \equiv\left(\psi_{1}, \ldots, \psi_{n}\right)$. According to the maximum principle should be $\psi_{0}(t)=$ const $\leq 0$. In the problem with a fixed time $T$ and with a free end of the trajectory are equalities

$$
\psi_{0}(T)=-1, \psi_{1}(T)=\psi_{2}(T)=\ldots=\psi_{n}(T)=0
$$

(transversality conditions; see $[2 ; 260]$ ), therefore $\psi_{0}(t) \equiv-1$, and the function $\tilde{H}$ takes the form

$$
\begin{gathered}
\tilde{H}(\psi, x, u, t)=-\left[\frac{1}{2}\left(x^{*} Q(t) x\right)+\frac{1}{2}\left(u^{*} R(t) u\right)-\right. \\
\left.-\psi^{*} A(t) x-\psi^{*} B(t) u-\psi^{*} h(t)\right] \equiv-\left[\frac{1}{2}\left(x^{*} Q(t) x\right)+\right. \\
\left.+\frac{1}{2}\left(u^{*} R(t) u\right)+p^{*} A(t) x+p^{*} B(t) u+p^{*} h(t)\right],
\end{gathered}
$$

where it is indicated: $p^{*} \equiv-\psi^{*}$. The function $\tilde{H}$ must reach a maximum on the optimal control $u=u(t)$, which means, that the function $\hat{H}\left(p^{*}, x, u, t\right) \equiv \frac{1}{2}\left(x^{*} Q(t) x\right)+\frac{1}{2}\left(u^{*} R(t) u\right)+p^{*} A(t) x+p^{*} B(t) u+p^{*} h(t)$ should reach to $u=u(t)$ the minimum. We note now that $\frac{d p_{j}}{d t}=-\frac{d \psi_{j}}{d t}(j=\overline{1, n})$, therefore, the auxiliary functions $p_{j} \equiv-\psi_{j}(t)$ satisfy the system of differential equations $\frac{d p_{j}}{d t}=\frac{\partial \tilde{H}}{\partial x_{j}}, j=\overline{1, n}$ (the equation $\dot{p}_{0}=\frac{\partial \tilde{H}}{\partial x_{0}}$ is not written out, since it is trivially satisfied, because $\left.\psi_{0}(t) \equiv-1, \frac{\partial \tilde{H}}{\partial x_{0}} \equiv 0\right)$. In terms of the function $\hat{H}$, this system can be written in the form

$$
\frac{d p_{j}}{d t}=-\frac{\partial \hat{H}}{\partial x_{j}}, j=\overline{1, n}
$$

Calculate $\frac{\partial \hat{H}}{\partial x_{j}}$. We have (consider that $Q(t)$ is a symmetric matrix)

$$
\begin{gathered}
\frac{\partial \hat{H}}{\partial x_{j}}=\frac{\partial}{\partial x_{j}}\left(\frac{1}{2} x^{*} Q(t) x+p^{*} A(t) x\right)=\frac{1}{2} e_{j}^{*} Q(t) x+ \\
+\frac{1}{2} x^{*} Q(t) e_{j}+p^{*} A(t) e_{j}=\frac{1}{2}\left(Q(t) x, e_{j}\right)+ \\
+\frac{1}{2}\left(Q(t) e_{j}, x\right)+\left(A(t) e_{j}, p\right)= \\
=\frac{1}{2}\left(x, Q(t) e_{j}\right)+\frac{1}{2}\left(Q(t) e_{j}, x\right)+\left(A(t) e_{j}, p\right)=\left(e_{j}, Q(t) x\right)+ \\
+\left(e_{j}, A^{*}(t) p\right)=\left(e_{j}, Q(t) x+A^{*}(t) p\right),
\end{gathered}
$$

where $e_{j}=\{0, \ldots, 0, \underset{(j)}{1}, 0, \ldots, 0\}, j=\overline{1, n}$. Therefore, the system (4) has the form

$$
\begin{gathered}
\frac{d p_{j}}{d t}=-\left(e_{j}, Q(t) x+A^{*}(t) p\right), j=\overline{1, n} \Leftrightarrow \\
\Leftrightarrow \frac{d p}{d t}=-Q(t) x-A^{*}(t) p .
\end{gathered}
$$


On the other hand, to search for the minimum points of the function $\hat{H}\left(p^{*}, x_{0}, x, u, t\right)$ relative to $u$, we must find its critical points (note that $R(t)$ is a symmetric matrix ):

$$
\begin{gathered}
\frac{\partial \hat{H}}{\partial u_{j}}=0, j=\overline{1, n} \Leftrightarrow \\
\Leftrightarrow \frac{1}{2} e_{j}^{*} R(t) u+\frac{1}{2} u^{*} R(t) e_{j}+p^{*} B(t) e_{j}=0 \Leftrightarrow \\
\Leftrightarrow\left(e_{j}, R(t) u\right)=-\left(B(t) e_{j}, p\right) \Leftrightarrow \\
\Leftrightarrow\left(e_{j}, R(t) u\right)=-\left(e_{j}, B^{*}(t) p\right), j=\overline{1, n} \\
\Leftrightarrow R(t) u=-B^{*}(t) p \Leftrightarrow u=-R^{-1}(t) B(t)^{*} p .
\end{gathered}
$$

So, the only one critical point $u=-R^{-1}(t) B^{*}(t) p$ is obtained. In order to check whether it will realize the minimum of the function $\hat{H}$ for $u$, consider the matrix of the second derivatives:

$$
\begin{gathered}
\frac{\partial^{2} \hat{H}}{\partial u_{j} \partial u_{k}}=\frac{\partial}{\partial u_{k}}\left[\left(e_{j}, R(t) u\right)+\left(e_{j}, B^{*}(t) p\right]=\right. \\
=\frac{\partial}{\partial u_{k}}\left(e_{j}, R(t) u\right)=\left(e_{j}, R(t) e_{k}\right)=R_{j k}(t), j, k=\overline{1, n},
\end{gathered}
$$

where $R_{j k}$ are the elements of the matrix $R(t)$. This shows that the matrix $\left(\frac{\partial^{2} \hat{H}}{\partial u_{j} \partial u_{k}}\right)$ does not depend on $u$. Since $R(t)$ is a positive definite matrix, then the point $u=-R^{-1}(t) B^{*}(t) p$ is indeed the minimum point of the function $\hat{H}$ for $u$. So, if the optimal control of problem (1)-(2) exists, then it necessarily has the form $u=-R^{-1}(t) B^{*}(t) p$, where $p=p(t)$ satisfies system (5) and $x=x(t)$ is calculated from the system (3). In other words, the optimal system has the form

$$
\begin{gathered}
\frac{d x}{d t}=A(t) x-B(t) R^{-1}(t) B^{*}(t) p+h(t), x(0)=x^{0} \\
\frac{d p}{d t}=-Q(t) x-A^{*}(t) p, p(T)=0 .
\end{gathered}
$$

It follows from [3] that the control $u=-R^{-1}(t) B^{*}(t) p$, where $p=p(t)$ satisfies system (6), is optimal, and the corresponding trajectory $x=x(t)$ is the optimal trajectory. The boundary-value problem (6) with continuous matrices $A(t), B(t), R(t), Q(t)$ and with continuous function $h(t)$ on a segment $[0, T]$ can be ambiguously solvable, and then the optimal control $u=-R^{-1}(t) B^{*}(t) p$ is calculated ambiguously. For the unique solvability of problem (6), it is necessary to require that the corresponding homogeneous boundary value problem

$$
\begin{gathered}
\frac{d x}{d t}=A(t) x-B(t) R^{-1}(t) B^{*}(t) p, x(0)=0 ; \\
\frac{d p}{d t}=-Q(t) x-A^{*}(t) p, p(T)=0 .
\end{gathered}
$$

Has only a trivial solution $(x(t), p(t)) \equiv 0$. This will take place, for example, in the case when $h(t) \equiv 0$ and $p(t)$ is linear depends on phase coordinates: $p(t)=K(t) x(t)$. Indeed, in this case (as shown in $[3 ; 318,319]$ ), the $(n \times n)$ - matrix $K(t) \not \equiv 0$ is symmetric and satisfies the nonlinear Riccati matrix differential equation:

$$
\begin{gathered}
\dot{K}=-K \cdot A(t)-A^{*}(t) \cdot K+ \\
+K \cdot B(t) R^{-1}(t) \cdot B^{*}(t) \cdot K-Q(t), K(T)=0(t \in[0, T]),
\end{gathered}
$$

and homogeneous problem $\left(6_{0}\right)$ takes the form

$$
\begin{gathered}
\frac{d x}{d t}=\left[A(t)-B(t) R^{-1}(t) B^{*}(t) K(t)\right] x, x(0)=0 \\
p(t)=K(t) x(t)
\end{gathered}
$$

This problem has only one solution $(x(t), p(t)) \equiv 0$.

\section{Singularly perturbed control problems. Building an optimal system}

We now consider a singularly perturbed control system

$$
\begin{gathered}
\varepsilon \dot{x}=A(t) x(t, \varepsilon)+B(t) u(t, \varepsilon)+f(t), x(0, \varepsilon)=x^{0}, 0 \leq t \leq T ; \\
J_{\varepsilon}(u)=\frac{1}{2} \int_{0}^{T}\left(x^{*} Q(t) x+u^{*} R(t) u\right) \exp \left(\frac{1}{\varepsilon} \int_{T}^{t} \mu(\theta) d \theta\right) d t,
\end{gathered}
$$

where $\varepsilon>0$ is a small parameter, $x(t, \varepsilon), f(t)$ are $n$ - dimensional, $u(t, \varepsilon)$ is $m$-dimensional vector functions, $x^{0}$ is a constant $n$-dimensional vector; $A(t)$ is $(n \times n)$-matrix; $B(t)$ is $(n \times m)$-matrix; $Q(t)$ is a symmetric 
non-negative definite $(n \times n)$ - matrix; $R(t)$ is a symmetric positive definite $(m \times m)$ - matrix, $\mu(t)$ is a scalar function, $t \in[0, T], *$ is a transposition sign. It is required to transfer the system (7) from a given initial position $x(0)=x^{0}$ to a position $x(T)$ in a fixed time $T<+\infty(x(T)$ is not fixed) so that the functional $J(u)$ takes the minimum value. In order to obtain asymptotic representations for $x(t, \varepsilon)$ and $u(t, \varepsilon)$ in the form of series in powers of $\varepsilon$, we require the following conditions to be satisfied:

$1^{0}$. The elements of the matrices $A(t), B(t), Q(t)$ and $R(t)$, as well as the components of the vector $f(t)$ and the scalar function $\mu(t)$ belong to $C^{\infty}([0, T], \mathrm{R})$.

Applying the Pontryagin's maximum principle (see system (1) in the previous section) and taking into account that the role of $A(t)$ is played by the matrix $\frac{1}{\varepsilon} A(t)$, role $B(t)$ - matrix $\frac{1}{\varepsilon} B(t)$, role $Q(t)-$ matrix $Q(t) \exp \left(\frac{1}{\varepsilon} \int_{T}^{t} \mu(\theta) d \theta\right)$; role $R(t)-\operatorname{matrix} R(t) \exp \left(\frac{1}{\varepsilon} \int_{T}^{t} \mu(\theta) d \theta\right) ;$ role $h(t)$ - function $\frac{1}{\varepsilon} f(t)$, we get the following optimal system:

$$
\begin{gathered}
\varepsilon^{2} \dot{x}=\varepsilon A(t) x-B(t) R^{-1}(t) B^{*}(t) \exp \left(-\frac{1}{\varepsilon} \int_{T}^{t} \mu(\theta) d \theta\right) p+\varepsilon f(t), x(0, \varepsilon)=x^{0}, \\
\varepsilon \dot{p}=-\varepsilon Q(t) \exp \left(\frac{1}{\varepsilon} \int_{T}^{t} \mu(\theta) d \theta\right) x-A^{*}(t) p, p(T, \varepsilon)=0 .
\end{gathered}
$$

Doing successive replacements

$$
\varepsilon x=y, \quad \exp \left(-\frac{1}{\varepsilon} \int_{T}^{t} \mu(\theta) d \theta\right) p=q, \quad\{y, q\}=z,
$$

and taking into account that

$$
\varepsilon \cdot \frac{d}{d t} p(t)=\left(\varepsilon \cdot \frac{d}{d t} q(t)\right) e^{\frac{1}{\varepsilon} \int_{T}^{t} \mu(\theta) d \theta}+q(t) \mu(t) e^{\frac{1}{\varepsilon} \int_{T}^{t} \mu(\theta) d \theta},
$$

we arrive at the following singularly perturbed boundary value problem with weak inhomogeneity:

$$
\begin{gathered}
\varepsilon \frac{d}{d t} y(t)=A(t) y(t)-B(t) \cdot R^{-1}(t) \cdot B^{*}(t) q(t)+\varepsilon f(t) \\
\varepsilon \frac{d}{d t} q(t)=-q(t) \mu(t)-Q(t) y(t)-A^{*}(t) \cdot q(t)
\end{gathered}
$$

or

$$
\begin{aligned}
& \varepsilon \dot{z}=S(t) z+\varepsilon h(t), \quad 0 \leq t \leq T \\
& G z \equiv M z(0, \varepsilon)+N z(T, \varepsilon)=\varepsilon \alpha
\end{aligned}
$$

where $S(t)$ is $(2 n \times 2 n)$-matrix with elements from the class $C^{\infty}[0, T]$ :

$$
S(t)=\left(\begin{array}{cc}
A & -B R^{-1} B^{*} \\
-Q & -\left(A^{*}+\mu I\right)
\end{array}\right)
$$

where $M=\operatorname{diag}(1, \ldots, 1,0, \ldots, 0), N=\operatorname{diag}(0, \ldots, 0,1, \ldots, 1), h(t)=f(t), 0, \ldots 0, \alpha=x^{0}, 0, \ldots, 0$ are $2 n-$ dimensional vectors. In this case, the optimal control (see 1 ) will be

$$
u(t)=-\frac{1}{\varepsilon} R^{-1}(t) B^{*}(t) q(t) .
$$

\section{Regularization of the optimal system. Construction of solutions of iterative problems}

Without detracting from the community, we may assume that $T=1$. Let $b_{j}(t), d_{j}(t) \quad(j=\overline{1,2 n})$ are eigenvectors of matrices $S(t)$ and $S^{*}(t)$ corresponding to eigenvalues $\lambda_{j}(t)$ and $\bar{\lambda}_{j}(t)$, respectively, and, moreover, $\left(b_{j}(t), d_{j}(t)\right)=\delta_{i j}$ is Kronecker's symbol. Suppose that besides the condition $1^{0}$, two more conditions are performed:

$2^{0}$. The spectrum $\left\{\lambda_{j}(t)\right\}$ of the matrix $S(t)$ has the properties:

a) $\lambda_{j}(t) \neq 0, j=\overline{1,2 n}, \forall t \in[0,1]$

b) $\lambda_{i}(t) \neq \lambda_{j}(t), i \neq j, i, j=\overline{1,2 n}, \forall t \in[0,1]$

c) $\operatorname{Re} \lambda_{j}(t)<0, j=\overline{1, n}, \operatorname{Re} \lambda_{j}(t) \geq 0, j=\overline{n+1,2 n}, \forall t \in[0,1]$;

d) $\operatorname{Re} \lambda_{1}(t) \leq \operatorname{Re} \lambda_{2}(t) \leq \ldots \leq \operatorname{Re} \lambda_{2 n}(t)$. 
$3^{0} \cdot \operatorname{det}\left(b_{i j}(0)\right)_{i, j=1}^{n} \cdot \operatorname{det}\left(b_{i j}(1)\right)_{i, j=n+1}^{2 n} \neq 0$.

Here $b_{j}=\operatorname{colon}\left(b_{i j}, \ldots, b_{2 n j}\right), j=\overline{1,2 n}$; the conditions $3^{0}$ mean that in the matrix $\mathfrak{B}(t)=\left(b_{i, j}(t)\right)_{i, j=\overline{1,2 n}}$ the left angle minor $\operatorname{det}\left(b_{i j}(t)\right)_{i, j=1}^{n}$ of order $n$ does not vanish at the point $t=0$, and the right angle minor $\operatorname{det}\left(b_{i j}(t)\right)_{i, j=n+1}^{2 n}$ of order $n$ does not vanish at the point $t=1$.

The listed conditions $1^{0}-3^{0}$ are realizable. To verify this, consider the following scalar problem:

$$
\begin{gathered}
\varepsilon\left(\frac{d}{d t} x(t)\right)=-x(t)+e^{t} u(t)+f(t), x(0)=x^{0}(0 \leq t \leq 1) ; \\
J_{\varepsilon}(u)=\frac{1}{2} \int_{0}^{1}\left(x(t)^{2}+u(t)^{2}\right) e^{\frac{t-1}{\varepsilon}} d t \rightarrow \min .
\end{gathered}
$$

By completing the replacement (8), we obtain the optimal system

$$
\begin{gathered}
\varepsilon\left(\begin{array}{c}
\dot{y} \\
\dot{z}
\end{array}\right)=\left[\begin{array}{cc}
-1 & -e^{2 t} \\
-1 & 2
\end{array}\right]\left(\begin{array}{c}
y \\
z
\end{array}\right)+\varepsilon\left(\begin{array}{c}
f(t) \\
0
\end{array}\right) \quad(0 \leq t \leq 1) \\
y(0)=\varepsilon x^{0}, \quad q(1)=0
\end{gathered}
$$

The eigenvalues and eigenvectors of the matrix $S(t)$ are follows:

$$
\begin{aligned}
& \lambda_{1}(t)=\frac{1}{2}-\frac{1}{2} \sqrt{9+4 e^{2 t}} \leftrightarrow b_{1}(t)=\left(\begin{array}{c}
\frac{2 e^{2 t}}{-3+\sqrt{9+4 e^{2 t}}} \\
1
\end{array}\right), \\
& \lambda_{2}(t)=\frac{1}{2}+\frac{1}{2} \sqrt{9+4 e^{2 t}} \leftrightarrow b_{2}(t)=\left(\begin{array}{c}
\frac{-2 e^{2 t}}{3+\sqrt{9+4 e^{2 t}}} \\
1
\end{array}\right) .
\end{aligned}
$$

Obviously, all the conditions $1^{0}-3^{0}$ for them are realized.

We draw attention to the fact that in the considerate problem may arise a situation when some points of the spectrum on separate values (or even on some continual set) of independent variable can become purely imaginary. This situation is not amenable to the study of the known methods of asymptotic integration (for example, using the Vasilyeva-Butuzov method of boundary functions [4-7]. However, it can be fully studied using the Lomov's regularization method $[1,8-10]$. Note, that the regularization method $[1,8]$ allows us to investigate a wide class of problems in the theory of singular perturbations [11-25].

For the regularization of problem (9), we apply the algorithm of the regularization method, developed for singularly perturbed problems in [1]. We introduce regularizing variables

$$
\begin{aligned}
& \tau_{k}=\frac{1}{\varepsilon} \int_{t_{k}}^{t} \lambda_{k}(s) d s \equiv \varphi_{k}\left(t, \frac{1}{\varepsilon}\right), k=\overline{1,2 n} ; \\
& t_{1}=\ldots=t_{n}=0, \quad t_{n+1}=\ldots=t_{2 n}=1
\end{aligned}
$$

and consider a new function $\tilde{z}=\tilde{z}(t, \tau, \varepsilon)$, for which we set the following problem:

$$
\begin{aligned}
& \varepsilon \frac{\partial \tilde{z}}{\partial t}+\sum_{j=1}^{2 n} \lambda_{j}(t) \frac{\partial \tilde{z}}{\partial \tau_{j}}-S(t) \tilde{z}=\varepsilon h(t) \\
& G \tilde{z}(t, \tau, \varepsilon) \equiv M z\left(M_{0}, \varepsilon\right)+N \tilde{z}\left(M_{1}, \varepsilon\right)=\varepsilon \alpha
\end{aligned}
$$

where

$$
M_{0}\left(0, \varphi\left(0, \frac{1}{\varepsilon}\right)\right), M_{1}\left(1, \varphi\left(1, \frac{1}{\varepsilon}\right)\right), \varphi\left(t, \frac{1}{\varepsilon}\right) \equiv\left(\varphi_{1}\left(t, \frac{1}{\varepsilon}\right), \ldots, \varphi_{2 n}\left(t, \frac{1}{\varepsilon}\right)\right) .
$$

If $\tilde{z}=\tilde{z}(t, \tau, \sigma, \varepsilon)$ is a solution to problem (11), then the restriction $z(t, \varepsilon) \equiv \tilde{z}\left(t, \varphi\left(t, \frac{1}{\varepsilon}\right), \varepsilon\right)$ will obviously be a solution to problem (9). The resulting problem (11) is regular in $\varepsilon$, and therefore we are looking for its solution in the form of a series

$$
\tilde{z}=\sum_{i=0}^{\infty} \varepsilon^{i} z_{i}(t, \tau)
$$

by non-negative powers of the parameter $\varepsilon$. To determine the coefficients of this series, we obtain the following iteration systems:

$$
L_{0} z_{0} \equiv \sum_{j=1}^{2 n} \lambda_{j}(t) \frac{\partial z_{0}}{\partial \tau_{j}}-S(t) z_{0}=0, \quad G z_{0}(t, \tau) \equiv M z_{0}\left(M_{0}\right)+N z_{0}\left(M_{1}\right)=0,
$$




$$
\begin{gathered}
L_{0} z_{1}=h(t)-\frac{\partial z_{0}}{\partial t}, G z_{1}=\alpha \\
L_{0} z_{i}=-\frac{\partial z_{i-1}}{\partial t}, G z_{i}=0, \quad i=2,3, \ldots .
\end{gathered}
$$

In order to study the solvability of problems $\left(13_{0}\right),\left(13_{1}\right),\left(13_{i}\right)$, consider the general iterative system

$$
L_{0} \xi=H(t, \tau, \sigma)
$$

We will find a solution to system (14) in the space of functions

$$
\left.U=\left\{\xi(t, \tau): \xi=\sum_{k=1}^{2 n} \xi_{k}(t) e^{\tau_{k}}+\xi_{0}(t) \xi_{k}(t) \in C^{\infty}([0,1]), \mathbb{C}^{2 n}\right), k=\overline{0,2 n}\right\}
$$

in which is the following scalar (for each $t \in[0,1]$ ) product is introduced

$$
<\xi(t, \tau), \zeta(t, \tau)>=\sum_{k=0}^{2 n}\left(\xi_{k}(t), \zeta_{k}(t)\right), \quad \xi=\xi(t, \tau), \zeta(t, \tau) \in U
$$

where $($,$) is the usual scalar product in the complex space \mathbb{C}^{2 n}$. Suppose that the right-hand side of system (14) belongs to $U$, that is $H(t, \tau)=\sum_{k=1}^{2 n} h_{k}(t) e^{\tau_{k}}+H_{0}(t) \in U$. The following assertion holds true, which is proved in the same way as the analogous assertion in [1].

Theorem 1. If conditions $1^{0}, 2^{0}(a, b, c)$ are satisfied and $H(t, \tau) \in U$, then for the solvability of system (14) in space $U$, it is necessary and sufficient that

$$
<H(t, \tau,), d_{k}(t) e^{\tau_{k}}>\equiv 0, \forall t \in[0,1], k=\overline{1,2 n} .
$$

Remark 1. Under the conditions of Theorem 1 the system (14) has the following solution in the space $U$ :

$$
\xi(t, \tau)=\sum_{k=1}^{2 n}\left(\alpha_{k}(t) b_{k}(t)+\sum_{s=1, s \neq k}^{2 n} H_{k s}(t) b_{s}(t)\right) e^{\tau_{k}}+\sum_{k=1}^{n} H_{0 k}(t) b_{k}(t)
$$

where $\alpha_{k}(t) \in C^{\infty}\left([0,1], \mathbb{C}^{1}\right)$ are arbitrary functions, $H_{k s}(t) \equiv\left(\lambda_{k}(t)-\lambda_{s}(t)\right)^{-1}\left(H_{k}(t), d_{s}(t)\right)$;

$$
H_{0 k}(t)=-\left(H_{0}(t), d_{k}(t)\right) / \lambda_{k}(t), k, s=\overline{1,2 n} .
$$

Theorem 2. Let the conditions $1^{0}-3^{0}$ be satisfied, $H(t, \tau) \in U$ satisfies the requirements (15). Then the system (14) under boundary conditions $G \xi=\xi^{0}$ and additional conditions

$$
<-\frac{\partial \xi}{\partial t}+g(t), d_{k}(t) e^{\tau_{k}}>\equiv 0, \overline{1,2 n}, \forall t \in[0,1]
$$

where $g(t) \in C^{\infty}\left([0,1], \mathbb{C}^{2 n}\right)$ is a known function, is uniquely solvable in $U$ for $\varepsilon \in\left(0, \varepsilon_{0}\right]$, where $\varepsilon_{0}>0$ is sufficiently small.

Proof. We use the conditions of orthogonality (17) and obtain equations for the unknown functions $\alpha_{k}(t)$ in the representation (16):

$$
\dot{\alpha}_{k}(t)+\left(\dot{b}_{k}(t), d_{k}(t)\right) \alpha_{k}=-\sum_{s=1, s \neq k}^{2 n} H_{k s}\left(\dot{b}_{s}(t), d_{k}(t)\right), k=\overline{0,2 n} .
$$

From equations (18) we find

$$
\alpha_{k}(t)=e^{-\int_{0}^{t}\left(\dot{b}_{k}, d_{k}\right) d \theta}\left[\alpha_{k}(0)-\sum_{s=1, s \neq k}^{2 n} \int_{0}^{t} e^{\int_{0}^{x}\left(\dot{b}_{k}, d_{k}\right) d \theta} H_{k s}(x)\left(\dot{b}_{s}(x), d_{k}(x)\right) d x\right],
$$


where $\alpha_{k}(0), k=\overline{1,2 n}$, are while unknown numbers. Subordinate the vector function (16) to the boundary condition $G \xi=\xi^{0} \Leftrightarrow M \xi\left(0, \varphi\left(0, \frac{1}{\varepsilon}\right)\right)+N \xi\left(1, \varphi\left(1, \frac{1}{\varepsilon}\right)\right)=\xi^{0}$. To simplify the calculations, we write the solution (16) in the form

$$
\xi(t, \tau)=\Phi(t) \operatorname{diag}\left(e^{\tau_{1}}, \ldots, e^{\tau_{2 n}}\right) \alpha(t)+\hat{\xi}(t, \tau),
$$

where $\alpha(t)=\left\{\alpha_{1}(t), \ldots, \alpha_{2 n}(t)\right\}, \Phi(t) \equiv\left(b_{1}(t), \ldots, b_{2 n}(t)\right)$ is the matrix of the eigenvectors of the matrix $T(t)$, and by $\hat{\xi}(t, \tau)$ is denoted the particular solution of system (14):

$$
\hat{\xi}(t, \tau)=\sum_{k=1}^{2 n}\left(\sum_{s=1, s \neq k}^{2 n} H_{k s}(t) b_{s}(t)\right) e^{\tau_{k}}+\sum_{k=1}^{n} H_{0 k}(t) b_{k}(t) .
$$

The condition $G \xi=\xi^{0}$ gives:

$$
\begin{aligned}
& M \Phi(0) \operatorname{diag}\left(1, \ldots, 1, e^{\varphi_{n+1}\left(0, \frac{1}{\varepsilon}\right)}, \ldots, e^{\varphi_{2 n}\left(0, \frac{1}{\varepsilon}\right)}\right) \alpha(0)+ \\
& +N \Phi(1) \operatorname{diag}\left(e^{\varphi_{1}\left(1, \frac{1}{\varepsilon}\right)}, \ldots, e^{\varphi_{n}\left(1, \frac{1}{\varepsilon}\right)}, 1, \ldots, 1,\right) \alpha(1)= \\
= & l(\varepsilon), l(\varepsilon) \equiv \xi^{0}-M \hat{\xi}\left(0, \varphi\left(0, \frac{1}{\varepsilon}\right)\right)+N \hat{\xi}\left(1, \varphi\left(1, \frac{1}{\varepsilon}\right)\right) .
\end{aligned}
$$

From equality (19) we find that

$$
\alpha_{k}(1)=e^{-\int_{0}^{1}\left(\dot{b}_{k}, d_{k}\right) d \theta}\left[\alpha_{k}(0)-\sum_{s=1, s \neq k}^{2 n} \int_{0}^{1} e^{\int^{x}\left(\dot{b}_{k}, d_{k}\right) d \theta} H_{k s}(x)\left(\dot{b}_{s}(x), d_{k}(x)\right) d x\right], k=\overline{1,2 n},
$$

so

$$
\alpha(1)=\operatorname{diag}\left(e^{-\int_{0}^{1}\left(\dot{b}_{1}, d_{1}\right) d \theta}, \ldots, e^{-\int_{0}^{1}\left(\dot{b}_{2 n}, d_{2 n}\right) d \theta}\right) \alpha(0)+\beta,
$$

where $\beta$ is a constant vector having the form

$$
\begin{gathered}
\beta=-\left\{\sum_{s=1, s \neq 1}^{2 n} \int_{0}^{1} e^{\int^{x}\left(\dot{b}_{1}, d_{1}\right) d \theta} H_{1 s}(x)\left(\dot{b}_{s}(x), d_{1}(x)\right) d x, \ldots ;\right. \\
\left.\sum_{s=1, s \neq 1}^{2 n} \int_{0}^{1} e^{\int^{x}\left(\dot{b}_{2 n}, d_{2 n}\right) d \theta} H_{1 s}(x)\left(\dot{b}_{s}(x), d_{2 n}(x)\right) d x\right\} .
\end{gathered}
$$

Substituting $\alpha(1)$ in (20), we will have

$$
\begin{gathered}
{\left[M \Phi(0) \operatorname{diag}\left(1, \ldots, 1, e^{\varphi_{n+1}\left(0, \frac{1}{\varepsilon}\right)}, \ldots, e^{\varphi_{2 n}\left(0, \frac{1}{\varepsilon}\right)}\right)+\right.} \\
\left.+N \Phi(1) \operatorname{diag}\left(e^{\varphi_{1}\left(1, \frac{1}{\varepsilon}\right)-\int_{0}^{1}\left(\dot{b}_{1}, d_{1}\right) d \theta}, \ldots, e^{\varphi_{n}\left(1, \frac{1}{\varepsilon}\right)-\int_{0}^{1}\left(\dot{b}_{n}, d_{n}\right) d \theta}, e^{-\int_{0}^{1}\left(\dot{b}_{n+1}, d_{n+1}\right) d \theta}, \ldots, e^{-\int_{0}^{1}\left(\dot{b}_{2 n}, d_{2 n}\right) d \theta}\right)\right] \times \\
\times \alpha(0)=l(\varepsilon)-N \beta .
\end{gathered}
$$

We divide the matrix $\Phi(t)$ into blocks of size $n \times n: \Phi(t)=\left(\begin{array}{cc}\Phi_{11}(t) & \Phi_{12}(t) \\ \Phi_{21}(t) & \Phi_{22}(t)\end{array}\right)$ and we introduce the notation:

$$
\begin{gathered}
\Lambda_{1}(t)=\operatorname{diag}\left(\lambda_{1}(t), \ldots, \lambda_{n}(t)\right), \Lambda_{2}(t)=\operatorname{diag}\left(\lambda_{n+1}(t), \ldots, \lambda_{2 n}(t)\right) ; \\
G_{1}=\operatorname{diag}\left(-\int_{0}^{1}\left(\dot{b}_{1}, d_{1}\right) d \theta, \ldots,-\int_{0}^{1}\left(\dot{b}_{n}, d_{n}\right) d \theta\right) ; \\
G_{2}=\operatorname{diag}\left(-\int_{0}^{1}\left(\dot{b}_{n+1}, d_{n+1}\right) d \theta, \ldots,-\int_{0}^{1}\left(\dot{b}_{2 n}, d_{2 n}\right) d \theta\right) .
\end{gathered}
$$

Then the determinant $\Delta(\varepsilon)$ of the system (21) can be written as

$$
\Delta(\varepsilon)=\left|\begin{array}{cc}
\Phi_{11}(0) & \Phi_{12}(0) e^{\frac{1}{\varepsilon} \int_{1}^{0} \Lambda_{2}(\theta) d \theta} \\
\Phi_{21}(1) e^{\frac{1}{\varepsilon} \int_{0}^{1} \Lambda_{1}(\theta) d \theta+G_{1}} & \Phi_{22}(1) e^{G_{2}}
\end{array}\right| .
$$


To calculate it, we apply the block Gauss method (see [26;44, 45]). Multiply the first «column» of this determinant by $-\Phi_{11}^{-1}(0) \Phi_{12}(0) e^{\frac{1}{\varepsilon} \int_{1}^{0} \Lambda_{2}(\theta) d \theta}$ the matrix and adding the result to the second «column», we get that

$$
\Delta(\varepsilon)=\left|\begin{array}{cc}
\Phi_{11}(0) & 0 \\
\Phi_{21}(1) e^{\frac{1}{\varepsilon} \int_{0}^{1} \Lambda_{1}(\theta) d \theta+G_{1}} & K
\end{array}\right|=\operatorname{det} \Phi_{11}(0) \cdot \operatorname{det} K,
$$

where $K=\Phi_{22}(1) e^{G_{2}}-\Phi_{11}^{-1}(0) \Phi_{12}(0) e^{\frac{1}{\varepsilon} \int_{1}^{0} \Lambda_{2}(\theta) d \theta} \Phi_{21}(1) e^{\frac{1}{\varepsilon} \int_{0}^{1} \Lambda_{1}(\theta) d \theta+G_{1}}$. Considering conditions $\left.2^{0} \mathrm{c}\right)$, we conclude that $\Delta(\varepsilon) \rightarrow \Delta(0)=\operatorname{det} \Phi_{11}(0) \cdot \operatorname{det}\left[\Phi_{22}(1) e^{G_{2}}(\varepsilon \rightarrow+0)\right.$. By virtue of the condition $3^{0}$ the determinant $\Delta(0) \neq 0$, and therefore $\Delta(\varepsilon) \neq 0$ for $\varepsilon \in\left(0, \varepsilon_{0}\right]$ and $\varepsilon_{0}>0$ is sufficiently small. This means that system (21) has a unique solution $\alpha(0)=\alpha^{0}(\varepsilon)$. Substituting this solution into (19), we find uniquely the functions $\alpha_{k}(t)=\alpha_{k}(t, \varepsilon)$, and, therefore, we calculate the solution (16) of system (14) in the space $U$ in a unique way. The theorem is proved.

\section{Correct solvability of a singularly perturbed two-point boundary value problem and estimation of the remainder term}

Applying Theorems 1, 2 to iterative problems $\left(13_{i}\right)$, we find in a unique way solutions of these problems in space $U$ and construct series (12). Arguing by analogy with the monograph [1;107-126], we prove the following result.

Lemma 1. Let the conditions $1^{0}-3^{0}$ be fulfilled. Then the function $z_{\varepsilon N}(t)=S_{N}\left(t, \varphi\left(t, \frac{1}{\varepsilon}\right)\right.$, $\varepsilon) \equiv \sum_{i=0}^{N} \varepsilon^{i} z_{i}\left(t, \frac{\varphi(t)}{\varepsilon}\right)$ satisfies the problem

$$
\varepsilon \frac{d z_{\varepsilon N}}{d t}=S(t) z_{\varepsilon N}(t)+\varepsilon h(t)+\varepsilon^{N+1} R_{N}(t, \varepsilon), \quad G z_{\varepsilon N}(t)=\varepsilon \alpha,
$$

where $\left\|R_{N}(t, \varepsilon)\right\|_{C[0,1]} \leq \bar{R}_{N}=$ const for $\varepsilon \in\left(0, \varepsilon_{0}\right]\left(\varepsilon_{0}>0\right.$ is sufficiently small).

To substantiate the asymptotic convergence of the formal solution $z_{\varepsilon N}(t)=S_{N}\left(t, \varphi\left(t, \frac{1}{\varepsilon}\right), \varepsilon\right)$ of the problem (9) to its exact solution $z(t, \varepsilon)$, we must prove the solvability of an arbitrary boundary value problem

$$
\varepsilon \frac{d z}{d t}=S(t) z+h(t), G z(t, \varepsilon)=z^{0}, t \in[0, T],
$$

under the above conditions $1^{0}-3^{0}$ and give an estimate of its solution through $\left\|z^{0}\right\|$ and $\|h(t)\|$. Under conditions of stability of the spectrum $\left\{\lambda_{j}(t)\right\}$ of an operator $S(t)$, such an estimate was carried out using the Green function (see, for example, [1]), the construction of which essentially uses a rather strict condition $2^{0} \mathrm{~d}$ ). Here we propose another procedure based on the study of a special integral equation equivalent to system (22). The implementation of this procedure (its main ideas are presented in [27]) makes it possible to avoid constructing the Green function, and also to get rid of condition $2^{0} \mathrm{~d}$ ). We formulate some of the statements from [27], which will be used later.

Consider a more general, than (22), boundary value problem

$$
\frac{d w}{d t}=S(t) w+h(t), l w \equiv M_{1} w(0)+N_{1} w(T)=w^{0}, t \in[0, T]
$$

not containing a parameter. We assume that $M_{1}$ and $N_{1}$ are arbitrary $(m \times m)$-matrices, $w=\left\{w_{1}, \ldots, w_{m}\right\}, S(t)$ is a well-known $(m \times m)$-matrix, $h(t)=\left\{h_{1}, \ldots, h_{m}\right\}$ is a well-known vector function, $w^{0}=\left\{w_{1}^{0}, \ldots, w_{m}^{0}\right\}$ is a well-known constant vector. We formulate conditions under which the boundary value problem (23) is solvable.

Let $\Phi(t)$ be the fundamental matrix of solutions of the corresponding homogeneous system $\dot{w}=S(t) w$ with columns $c_{j}(t)$, i.e. $\Phi(t)=\left(c_{1}(t), \ldots, c_{m}(t)\right)$. Form the matrices

$$
\begin{gathered}
\Phi_{1}(t)=\left(c_{1}(t), \ldots, c_{k}(t) ; 0, \ldots, 0\right) ; \\
\Phi_{2}(t)=\left(0, \ldots, 0 ; c_{k+1}(t), \ldots, c_{m}(t)\right),
\end{gathered}
$$

where $k \in\{1, \ldots, m\}$ is an arbitrary number. The following properties of these matrices are obvious:

a) $\Phi_{1}(t)+\Phi_{2}(t)=\Phi(t)$; b) $\dot{\Phi}_{j}(t) \equiv S(t) \Phi_{j}(t), j=1,2$; c) $\dot{\Phi}_{1}(t)+\dot{\Phi}_{2}(t)=\dot{\Phi}(t)$. 
Lemma 2 [27]. Let the matrix $S(t) \in C^{\infty}\left([0, T], \mathbb{C}^{m \times m}\right), h(t) \in C^{\infty}\left([0, T], \mathbb{C}^{m}\right)$. Then the general solution of the system $\dot{w}=S(t) w+h(t)$ on the segment $[0, T]$ can be written as

$$
w\left(t, c_{0}\right)=\Phi(t) c_{0}+\Phi_{1}(t) \int_{0}^{t} \Phi^{-1}(\theta) h(\theta) d \theta+\Phi_{2}(t) \int_{T}^{t} \Phi^{-1}(\theta) h(\theta) d \theta,
$$

where $c_{0} \in C^{m}$ is an arbitrary constant vector.

Proof. Since $\Phi(t) c_{0}$ it is a general solution of the corresponding homogeneous system, it is necessary to show that the vector function

$$
\tilde{w}(t)=\Phi_{1}(t) \int_{0}^{t} \Phi^{-1}(\theta) h(\theta) d \theta+\Phi_{2}(t) \int_{T}^{t} \Phi^{-1}(\theta) h(\theta) d \theta
$$

is a particular solution to a non-homogeneous system of equations $\dot{w}=S(t) w+h(t)$. Using the properties a) - c) of the matrices $\Phi_{j}(t)$, we will have

$$
\begin{gathered}
\frac{d \tilde{w}}{d t}=\dot{\Phi}_{1}(t) \int_{0}^{t} \Phi^{-1}(\theta) h(\theta) d \theta+\Phi_{1}(t) \Phi^{-1}(t) h(t)+ \\
+\dot{\Phi}_{2}(t) \int_{T}^{t} \Phi^{-1}(\theta) h(\theta) d \theta+\Phi_{2}(t) \Phi^{-1}(t) h(t)= \\
=S(t) \Phi_{1}(t) \int_{0}^{t} \Phi^{-1}(\theta) h(\theta) d \theta+S(t) \Phi_{2}(t) \int_{T}^{t} \Phi^{-1}(\theta) h(\theta) d \theta+ \\
+\left[\Phi_{1}(t)+\Phi_{2}(t)\right] \Phi^{-1} h(t)=S(t)\left[\Phi_{1}(t) \int_{0}^{t} \Phi^{-1}(t)(\theta) h(\theta) d \theta+\right. \\
\left.+\Phi_{2}(t) \int_{T}^{t} \Phi^{-1}(\theta) h(\theta) d \theta\right]+h(t)=A(t) \tilde{w}(t)+h(t),
\end{gathered}
$$

that is, function (25) is indeed a solution of an non-homogeneous system $\dot{w}=S(t) w+h(t)$. The lemma is proved.

Lemma 3 [27]. Let the conditions of Lemma 2 be fulfilled. Then for the unique solvability of the boundary value problem (23) it is necessary and sufficient that

$$
\operatorname{det}\left[M_{1} \Phi(0)+N_{1} \Phi(T)\right] \neq 0 .
$$

If condition (26) is satisfied, then the solution of the problem (23) is given by formula (24), where the vector $c_{0}$ has the form

$$
\begin{gathered}
c_{0}=\left[M_{1} \Phi(0) c_{0}+M_{1} \Phi(T)\right]^{-1}\left(w^{0}-M_{1} \Phi_{2}(0) \int_{T}^{0} \Phi^{-1}(\theta) h(\theta) d \theta-\right. \\
\left.-N_{1} \Phi_{1}(T) \int_{0}^{T} \Phi^{-1}(\theta) h(\theta) d \theta\right) .
\end{gathered}
$$

Proof. Subject (24) to the boundary condition $l w=w^{0}$. We will have

$$
\begin{gathered}
M_{1} \Phi(0) c_{0}+M_{1} \Phi_{2}(0) \int_{T}^{0} \Phi^{-1}(\theta) h(\theta) d \theta+N_{1} \Phi(T) c_{0}+ \\
+N_{1} \Phi_{1}(T) \int_{0}^{T} \Phi^{-1}(\theta) h(\theta) d \theta=w^{0}
\end{gathered}
$$


or

$$
\begin{gathered}
\left.\left[M_{1} \Phi(0)+M_{2} \Phi(T)\right] c_{0}=w^{0}-M_{1} \Phi_{2}(0) \int_{T}^{0} \Phi^{-1}(\theta) h(\theta) d \theta\right)- \\
-N_{1} \Phi_{1}(t) \int_{0}^{T} \Phi^{-1}(\theta) h(\theta) d \theta .
\end{gathered}
$$

For the unique solvability of this system, it is necessary and sufficient to satisfy condition (26). At the same time, $c_{0}$ has the form (27). The lemma is proved.

We now turn to the study of the solvability of the boundary value problem (23). According to [1; 109, 110], under the assumption that $S(t) \in C^{1}\left([0, T], \mathbb{C}^{2 n \times 2 n}\right)$ transformation

$$
z=\left[B(t)\left(I+\varepsilon B_{1}(t)\right)\right] \eta(t, \varepsilon),
$$

where $B^{-1}(t) T(t) B(t)=\Lambda(t)=\operatorname{diag}\left(\lambda_{1}(t), \ldots, \lambda_{2 n}(t)\right)$;

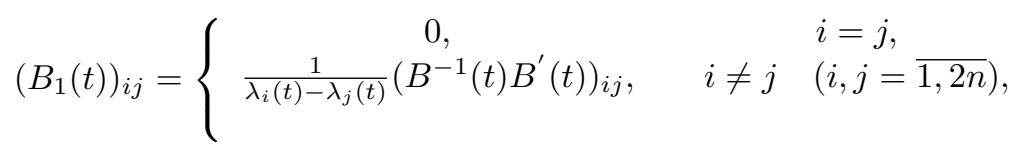

leads system (22) to the system

$$
\begin{gathered}
\varepsilon \frac{d \eta}{d t}=\Lambda_{0}(t, \varepsilon) \eta+\varepsilon^{2} C(t, \varepsilon) \eta+H_{1}(t, \varepsilon) \\
P_{1}(\varepsilon) \eta(0, \varepsilon)+P_{2}(\varepsilon) \eta(T, \varepsilon)=z^{0}
\end{gathered}
$$

where indicated:

$$
\begin{gathered}
P_{1}(\varepsilon)=M\left[B(0)\left(I+\varepsilon B_{1}(0)\right], \quad P_{2}(\varepsilon)=N\left[B(T)\left(I+\varepsilon B_{1}(T)\right] ;\right.\right. \\
\Lambda_{0}(t, \varepsilon)=\operatorname{diag}\left(\lambda_{1}(t)+\varepsilon \mu_{1}(t), \ldots, \lambda_{2 n}(t)+\varepsilon \mu_{2 n}(t)\right) ; \\
H_{1}(t)=\left[B(t)\left(I+\varepsilon B_{1}(t)\right]^{-1} h(t)\right.
\end{gathered}
$$

and $C(t, \varepsilon)$ is a known matrix. Let $\Phi(t, \varepsilon)$ be the fundamental solution system of a shortened system

$$
\varepsilon \frac{d z}{d t}=\Lambda_{0}(t, \varepsilon) z
$$

Obviously, it can be taken in the following form:

$$
\Phi(t, \varepsilon)=\left(\begin{array}{cc}
e^{\frac{1}{\varepsilon} \int_{0}^{t} \bar{\Lambda}(\theta, \varepsilon) d \theta} & 0 \\
0 & e^{\frac{1}{\varepsilon} \int_{T}^{t} \overline{\bar{\Lambda}}(\theta, \varepsilon) d \theta}
\end{array}\right)
$$

where

$$
\begin{gathered}
\bar{\Lambda}(t)=\operatorname{diag}\left(\lambda_{1}(t)+\varepsilon \mu_{1}(t), \ldots, \lambda_{n}(t)+\varepsilon \mu_{n}(t)\right) \\
\overline{\bar{\Lambda}}(t)=\operatorname{diag}\left(\lambda_{n+1}(t)+\varepsilon \mu_{n+1}(t), \ldots, \lambda_{2 n}(t)+\varepsilon \mu_{2 n}(t)\right) .
\end{gathered}
$$

Using (30) and Lemma 3, we reverse the system (28) and obtain an equivalent system of integral equations

$$
\begin{gathered}
\eta(t, \varepsilon)=\Phi(t, \varepsilon) c_{0}(\eta)+ \\
+\Phi_{1}(t, \varepsilon) \int_{0}^{t} \varepsilon \Phi^{-1}(s, \varepsilon) C(s, \varepsilon) \eta(s, \varepsilon) d s+ \\
+\frac{\Phi_{1}(t, \varepsilon)}{\varepsilon} \int_{0}^{t} \Phi^{-1}(s, \varepsilon) H_{1}(s, \varepsilon) d s+ \\
+\Phi_{2}(t, \varepsilon) \int_{T}^{t} \varepsilon \Phi^{-1}(s, \varepsilon) C(s, \varepsilon) \eta(s, \varepsilon) d s+ \\
+\frac{\Phi_{2}(t, \varepsilon)}{\varepsilon} \int_{T}^{t} \Phi^{-1}(s, \varepsilon) H_{1}(s, \varepsilon) d s,
\end{gathered}
$$


where

$$
\begin{gathered}
c_{0}(\eta)=\left[P_{1}(\varepsilon) \Phi(0, \varepsilon)+P_{2}(\varepsilon) \Phi(T, \varepsilon)\right]^{-1} \times \\
\times\left[z^{0}-P_{1}(\varepsilon) \Phi_{2}(0, \varepsilon) \int_{T}^{0} \varepsilon \Phi^{-1}(s, \varepsilon) C(s, \varepsilon) \eta(s, \varepsilon) d s-\right. \\
-P_{2}(\varepsilon) \Phi_{1}(T, \varepsilon) \int_{0}^{T} \varepsilon \Phi^{-1}(s, \varepsilon) C(s, \varepsilon) \eta(s, \varepsilon) d s- \\
-P_{1}(\varepsilon) \frac{\Phi_{2}(0, \varepsilon)}{\varepsilon} \int_{T}^{0} \Phi^{-1}(s, \varepsilon) H_{1}(s, \varepsilon) d s- \\
\left.-P_{2}(\varepsilon) \frac{\Phi_{1}(T, \varepsilon)}{\varepsilon} \int_{0}^{T} \Phi^{-1}(s, \varepsilon) H_{1}(s, \varepsilon) d s\right]
\end{gathered}
$$

and by $\Phi_{j}(t, \varepsilon)$ we denoted $(2 n \times 2 n)$-matrices

$$
\Phi_{1}(t, \varepsilon)=\operatorname{diag}\left(e^{\frac{1}{\varepsilon} \int_{0}^{t} \bar{\Lambda}(\theta, \varepsilon) \theta}, 0\right) ; \quad \Phi_{2}(t, \varepsilon)=\operatorname{diag}\left(0, e^{\frac{1}{\varepsilon} \int_{T}^{t} \overline{\bar{\Lambda}}(\theta, \varepsilon) \theta}\right) .
$$

Substituting (32) into (31), we write the integral system in operator form:

$$
\eta=A \eta \text {. }
$$

Obviously, the operator $A$ acts from space $C\left([0, T], \mathbb{C}^{2 n}\right)$ to itself. In assessing the norm $\left\|A \eta_{1}-A \eta_{2}\right\|$, we use the fact that the product $\Phi_{1}(t, \varepsilon) \Phi^{-1}(s, \varepsilon)$ is uniformly bounded of $\varepsilon$ (for sufficiently small $\varepsilon>0$ ) for $s$ and $t$ satisfying the inequalities $0 \leq s \leq t \leq T$, and the product $\Phi_{2}(t, \varepsilon) \Phi^{-1}(s, \varepsilon)$ is uniformly bounded (for sufficiently small $\varepsilon>0$ ) for $s$ and $t$ satisfying the inequalities $0 \leq t \leq s \leq T$. Let us show this. We have at $0 \leq s \leq t \leq T$ :

$$
\begin{gathered}
\left\|\Phi_{1}(t, \varepsilon) \Phi^{-1}(s, \varepsilon)\right\| \equiv \\
\equiv\left\|\exp \left\{\frac{1}{\varepsilon} \int_{s}^{t} \bar{\Lambda}(\theta) d \theta\right\}\right\|=\left\|\exp \left\{\frac{1}{\varepsilon} \int_{s}^{t} \operatorname{Re} \bar{\Lambda}(\theta) d \theta\right\}\right\| \leq \\
\leq \| \operatorname{diag}\left(\exp \left\{\frac{1}{\varepsilon} \int_{s}^{t} \operatorname{Re} \lambda_{1} d \theta\right\}, \ldots, \exp \left\{\frac{1}{\varepsilon} \int_{s}^{t} \operatorname{Re} \lambda_{n} d \theta\right\} \| \times\right. \\
\times \| \operatorname{diag}\left(\exp \left\{\int_{s}^{t} \operatorname{Re} \mu_{1} d \theta\right\}, \ldots, \exp \left\{\int_{s}^{t} \operatorname{Re} \mu_{n} d \theta\right\} \| \leq \nu_{1}=\right.\text { const; }
\end{gathered}
$$

because $\operatorname{Re} \lambda_{i}(\theta) \leq 0$ when $0 \leq s \leq \theta \leq t \leq T, i=\overline{1, n}$. When $0 \leq t \leq s \leq T$ we have

$$
\begin{gathered}
\left\|\Phi_{2}(t, \varepsilon) \Phi^{-1}(s, \varepsilon)\right\| \equiv \\
\equiv\left\|\exp \left\{\frac{1}{\varepsilon} \int_{s}^{t} \overline{\bar{\Lambda}} d \theta\right\}\right\|=\left\|\exp \left\{-\frac{1}{\varepsilon} \int_{t}^{s} \operatorname{Re} \overline{\bar{\Lambda}} d \theta\right\}\right\| \leq \\
\leq \| \operatorname{diag}\left(\exp \left\{-\frac{1}{\varepsilon} \int_{t}^{s} \operatorname{Re} \lambda_{n+1} d \theta\right\}, \ldots,\left(\exp \left\{-\frac{1}{\varepsilon} \int_{t}^{s} \operatorname{Re} \lambda_{2 n} d \theta\right\} \| \times\right.\right. \\
\times\left\|\operatorname{diag}\left(\exp \left\{\int_{s}^{t} \operatorname{Re} \mu_{n+1} d \theta\right\}, \ldots, \exp \left\{\int_{s}^{t} \operatorname{Re} \mu_{2 n} d \theta\right\}\right)\right\| \leq \\
\leq \nu_{2}=\text { const, }
\end{gathered}
$$

since $\operatorname{Re} \lambda_{j}(\theta) \geq 0$ when $0 \leq t \leq \theta \leq s \leq T, j=\overline{n+1,2 n}$. In this case, constants $\nu_{1}$ and $\nu_{2}$ does not depend on $\varepsilon$ when $\varepsilon \in\left(0, \varepsilon_{0}\right]$, where $\varepsilon_{0}>0$ is sufficiently small. 
We now turn to the estimate $\left\|A \eta_{1}-A \eta_{2}\right\| \equiv\left\|A \eta_{1}-A \eta_{2}\right\|_{C[0, T]}$. Using the boundedness of matrices $\Phi_{1}(t, \varepsilon) \times \Phi^{-1}(t, \varepsilon)$ and $\Phi_{2}(t, \varepsilon) \cdot \Phi^{-1}(t, \varepsilon)$, we will have

$$
\begin{gathered}
\left\|A \eta_{1}-A \eta_{2}\right\| \leq\left\|\Phi(t, \varepsilon)\left(c_{0}\left(\eta_{1}\right)-c_{0}\left(\eta_{2}\right)\right)\right\|+ \\
+\varepsilon \| \Phi_{1}(t, \varepsilon) \int_{0}^{t} \Phi^{-1}(s, \varepsilon) C(s, \varepsilon)\left(\eta_{1}(s, \varepsilon)-\eta_{2}(s, \varepsilon) d s \|+\right. \\
+\varepsilon \| \Phi_{2}(t, \varepsilon) \int_{T}^{t} \Phi^{-1}(s, \varepsilon) C(s, \varepsilon)\left(\eta_{1}(s, \varepsilon)-\eta_{2}(s, \varepsilon) d s \| \leq\right. \\
\leq \nu_{0}\left\|c_{0}\left(\eta_{1}\right)-c_{0}\left(\eta_{2}\right)\right\|+\varepsilon \nu_{3}\left\|\eta_{1}-\eta_{2}\right\|+\varepsilon \nu_{4}\left\|\eta_{1}-\eta_{2}\right\| .
\end{gathered}
$$

On the other hand,

$$
\begin{gathered}
\left\|c_{0}\left(\eta_{1}\right)-c_{0}\left(\eta_{2}\right)\right\| \leq\left\|\left(P_{1}(\varepsilon) \Phi(0, \varepsilon)+P_{2}(\varepsilon) \Phi(T, \varepsilon)\right)^{-1}\right\| \times \\
\times\left(\| \varepsilon P_{1}(\varepsilon) \Phi_{2}(0, \varepsilon) \int_{T}^{0} \Phi^{-1}(s, \varepsilon) C(s, \varepsilon)\left(\eta_{1}(s, \varepsilon)-\eta_{2}(s, \varepsilon) d s \|+\right.\right. \\
+\| \varepsilon P_{2}(\varepsilon) \Phi_{1}(T, \varepsilon) \int_{0}^{T} \Phi^{-1}(s, \varepsilon) C(s, \varepsilon)\left(\eta_{1}(s, \varepsilon)-\eta_{2}(s, \varepsilon) d s \|\right) \leq \\
\leq \varepsilon \nu_{5}\left\|\eta_{1}-\eta_{2}\right\| .
\end{gathered}
$$

Substituting this into the previous inequality, we get $\left\|A \eta_{1}-A \eta_{2}\right\| \leq \varepsilon \nu_{6}\left\|\eta_{1}-\eta_{2}\right\|$, where $\nu_{6}$ do not depend on $\varepsilon$ at $\varepsilon \in\left(0, \varepsilon_{0}\right]$. From here it follows that the operator $A$ is contraction operator in space $C\left([0, T], \mathbb{C}^{2 n}\right)$, and therefore, the equation (33) is uniquely solvable in $C\left([0, T], \mathbb{C}^{2 n}\right)$.

From $(31)$ and $(32)$, passing to the norms in $C\left([0, T], \mathbb{C}^{2 n}\right)$, we get

$$
\begin{gathered}
\|\eta(t, \varepsilon)\| \leq \nu_{0}\left\|c_{0}(\eta)\right\|+\varepsilon \nu_{7}\|\eta\|+\frac{\nu_{8}}{\varepsilon}\left\|H_{1}\right\| ; \\
\left\|c_{0}(\eta)\right\| \leq \nu_{9} .\left\|z^{0}\right\|+\varepsilon \nu_{10}\|\eta\|+\frac{\nu_{11}}{\varepsilon}\left\|H_{1}\right\|,
\end{gathered}
$$

which means, that

$$
\|\eta\| \leq \frac{1}{1-\varepsilon\left(\nu_{7}+\nu_{10} \nu_{0}\right)}\left(\nu_{0} \nu_{9}\left\|z^{0}\right\|+\frac{\nu_{8}+\nu_{0} \nu_{11}}{\varepsilon}\left\|H_{1}\right\|\right)
$$

Take $\varepsilon>0$ such that

$$
1-\varepsilon\left(\nu_{7}+\nu_{10} \nu_{0}\right) \geq \frac{1}{2}
$$

Then

$$
\|\eta\| \leq 2\left(\nu_{0} \nu_{9}\left\|z^{0}\right\|+\frac{\nu_{8}+\nu_{0} \nu_{11}}{\varepsilon}\left\|H_{1}\right\|\right) .
$$

Since $z=\left[B(t) I+\varepsilon B_{1}(t)\right] \eta(t, \varepsilon)$, then the initial boundary problem $(22)$ is uniquely solvable in $C^{1}\left([0, T], \mathbb{C}^{2 n}\right)$ and for its solution $z(t, \varepsilon)$ we have the estimate

$$
\|z(t, \varepsilon)\|_{C[0, T]} \leq K_{1}\left\|z^{0}\right\|+\frac{K_{2}}{\varepsilon}\|h\|_{C[0, T]} .
$$

However, all our calculations are correct only when

$$
\left|\operatorname{det}\left[P_{1}(\varepsilon) \Phi(0, \varepsilon)+P_{2}(\varepsilon) \Phi(T, \varepsilon)\right]\right| \geq \delta_{1}=\text { const }>0
$$

at $\varepsilon \in\left(0, \varepsilon_{0}\right]$. Insofar as $P_{1}(\varepsilon)=M B(0)+\varepsilon M B_{1}(0), P_{2}(\varepsilon)=N B(T)+\varepsilon N B_{1}(T)$, then inequality (35) for $\varepsilon \in\left(0, \varepsilon_{0}\right]$ follows from the fact that

$$
|\operatorname{det}[M B(0) \Phi(0, \varepsilon)+N B(T) \Phi(T, \varepsilon)]| \geq \delta_{2}=\text { const }>0
$$

for $\varepsilon \in\left(0, \varepsilon_{0}\right]$. This fact follows from the conditions $\left.\left.3^{0} a\right)-3^{0} c\right)$, what can be proved in the same way as the inequality $|\Delta(\varepsilon)| \geq \delta_{0}=$ const (see system (21) and the following calculations).

The following result is proved. 
Theorem 3. Suppose that $S(t) \in C^{1}\left([0, T], \mathbb{C}^{2 n \times 2 n}\right), h(t) \in C\left([0, T], \mathbb{C}^{2 n}\right)$ and the conditions $\left.1^{0}, 2^{0} a\right)-$ $\left.2^{0} c\right), 3^{0}$ are satisfied. Then for sufficiently small $\varepsilon \in\left(0, \varepsilon_{0}\right]$ the boundary value problem (22) has a unique solution $z(t, \varepsilon)$ and estimate (34) is valid for it.

Using the estimate (34) for the remainder term $r_{N}(t, \varepsilon)=z(t, \varepsilon)-z_{\varepsilon N}(t)$, as well as Lemma 1, we can easily prove the following statement.

Theorem 4. Let the conditions $\left.\left.1^{0}, 2^{0} \mathrm{a}\right)-2^{0} c\right), 3^{0}$ are fulfilled. Then the boundary value problem (9) for sufficiently small $\varepsilon>0\left(0<\varepsilon \leq \varepsilon_{0}\right)$ is uniquely solvable in the class $C^{1}\left([0, T], \mathbb{C}^{2 n}\right)$ and the estimate

$$
\left\|z(t, \varepsilon)-z_{\varepsilon N}(t)\right\|_{C[0, T]} \leq C_{N} \varepsilon^{N+1}
$$

holds true ( here $C_{N}>0$ is a constant independent of $\varepsilon \in\left(0, \varepsilon_{0}\right], z_{\varepsilon N}(t)=S_{N}\left(t, \varphi\left(t, \frac{1}{\varepsilon}\right), \varepsilon\right)$ the formal asymptotic solution constructed above.

So, we have obtained the asymptotic solution of the problem (9) in the form of a series (12), taken at the restriction $\tau=\varphi\left(t, \frac{1}{\varepsilon}\right)$. Using equations (8) and (10), we construct the asymptotics of the optimal control $u(t, \varepsilon)$ and the optimal trajectory $x(t, \varepsilon)$.

Remark 2. Due to the uniqueness of the solution of the system $\left(13_{0}\right)$ in space $U$, it will have only a trivial solution $z_{0}=z_{0}(t, \tau) \equiv 0$, therefore the asymptotic series for the optimal control (10) and the optimal trajectory $x(t, \varepsilon)=\frac{1}{\varepsilon} y(t, \varepsilon)$ will not contain coefficients with a negative degree of the parameter $\varepsilon$.

Remark 3. Condition $2^{0} \mathrm{~d}$ ) is related to the construction of the Green function for the boundary value problem (9) and its application in estimating the remainder term (see $[1 ; 108-126])$. Using our technique, one can do without constructing the Green function and then condition $2^{0} \mathrm{~d}$ ) can be removed.

\section{Acknowledgement}

This work is supported by the grant № AP05133858 «Contrast structures in singularly perturbed equations and their application in the theory of phase transitions» (2018-2020) by the Committee of Science, Ministry of Education and Science of the Republic of Kazakhstan.

\section{References}

1 Ломов С.А. Введение в общую теорию сингулярных возмущений / С.А. Ломов. - М.: Наука, 1981.

2 Ройтенберг Я.Н. Автоматическое управление / Я.Н. Ройтенберг. - М.: Наука, 1971.

3 Болтянский И.Г. Достаточные условия оптимальности и обоснования метода динамического программирования / И.Г. Болтянский // Изв. АН СССР. Сер. Матем. - Т. 28, № 3. - 1964. - С. 481514.

4 Глизер В.Я. Метод пограничного слоя при решении некоторых задач аналитического проектирования регулятора / В.Я. Глизер, В.Я. Глизер, М.Г. Дмитриев // Тез. докл. Всесоюз. конф. по асимп. методам. - Фрунзе: Илим, 1975. - С. 112-115.

5 Васильева А.Б. Об асимптотике решения типа контрастной структуры / А.Б. Васильева, В.Ф. Бутузов // Матем. заметки. - 1987. - Т. - 42. - №. 6. - С. 831-841.

6 Бутузов В.Ф. Асимптотическая теория контрастных структур / В.Ф. Бутузов, А.Б. Васильева, Н.Н. Нефедов // Автомат. и телемех. - 1977. - 7. - С. 3-32.

7 Васильева А.Б. Контрастные структуры в сингулярно возмущенных задачах / А.Б. Васильева, В.Ф. Бутузов, Н.Н. Нефедов // Фундамент. и приклад. матем. - 1998. - Т. 4(3). - С. 799-851.

8 Ломов С.А. Основы математической теории пограничного слоя / С.А. Ломов, И.С. Ломов. - М.: Изд-во МГУ, 2011.

9 Ломов С.А. Теория сингулярных возмущений в случае спектральных особенностей предельного оператора / С.А. Ломов, А.Г. Елисеев // Матем. сб. - 1986. - Т. 131 (173), № 4 (26). - С. 544-557.

10 Бободжанов А.А. Регуляризация оптимальных сингулярно возмущенных систем с быстро меняющейся демпфирующей функцией / А.А. Бободжанов, Н.А. Рашепкина, В.Ф. Сафонов // Вестн. МЭИ. - 1998. - № 6. - С. 18-26.

11 Иманбаев Н.С. Алгоритм метода регуляризации для сингулярно возмущенной задачи с нестабильным значением ядра интегрального оператора / Н.С. Иманбаев, Б.Т. Калимбетов, М.А. Темирбеков // Вестн. Караганд. ун-та. Сер. математика. - 2013. - № 4(72). - С. 64-70. 
12 Калимбетов Б.Т. Математическое описание внутреннего пограничного слоя для нелинейной интегродифференциальной системы / Б.Т. Калимбетов, Б.И. Ескараева, М.А. Темирбеков // Вестн. Караганд. ун-та. Сер. математика. - 2014. - № 3(75). - С. 77-87.

13 Ескараева Б.И. Дискретный пограничный слой в случае нулевых точек спектра для систем интегродифференциальных уравнений / Б.И. Ескараева, Б.Т. Калимбетов, М.А. Темирбеков // Вестн. Караганд. ун-та. Сер. математика. - № 3(75). - 2014. - С. 88-95.

14 Kalimbetov B.T. Internal boundary layer for integral-differential equations with zero spectrum of the limit operator and rapidly changing kernel / B.T. Kalimbetov, B.I. Yeskarayeva, A.S. Tolep // Applied Mathematical Sciences. - 9. - 141-144. - 2015. - P. 7149-7165.

15 Kalimbetov B.T. Asymptotic solution of singular perturbed problems with an instable spectrum of the limiting operator / B.T. Kalimbetov, M.A. Temirbekov, Zh.O. Habibullaev // Abstract and Applied Analysis. - 2012. Article ID 120192.

16 Kalimbetov B.T. Regularized asymptotical solutions of integro-differential systems with spectral singularites / B.T. Kalimbetov, N.S. Imanbaev, D.A. Sapakov, L.T. Tashimov // Advances in Difference Equations. - 2013. - Vol. 109. - DOI: 10.1186/1687-1847-2013-109.

17 Safonov V.F. A regularization method for systems with instable spectral of the kernel of the integral operator / V.F. Safonov, B.T. Kalimbetov // Differential Equations. - 31. - 4. - 1995. — P. 647-656.

18 Safonov V.F. Regularized asymptotic solutions of the initial problem of systems of integro-partial differential equations / V.F. Safonov, A.A. Bobodzhanov // Mathematical Notes. - 102. - 1. - 2017. - P. 22-30.

19 Safonov V.F. Regularized asymptotics of solutions to integro-differential partial differential equations with rapidly varying kernels / V.F. Safonov, A.A. Bobodzhanov // Ufimsk. Mat. Zh. - 10. - 2. - 2018. P. 3-12.

20 Bobodzhanov A.A. A generalization of the regularization method to the singularly perturbed integrodifferential equations with partial derivatives / A.A. Bobodzhanov, V.F. Safonov // Russian Math. (Iz. vuz). - 62. - 3. - 2018. - P. 6-17.

21 Bobodzhanov A.A. A problem with inverse time for a singularly perturbed integro-differential equation with diagonal degeneration of the kernel of high order / A.A. Bobodzhanov, V.F. Safonov // Izv. Math. - 80. - 2. - 2016. - P. 285-298.

22 Bobodzhanov A.A. Asymptotic solutions of Fredholm integro-differential equations with rapidly changing kernels and irreversible limit operator / A.A. Bobodzhanov, V.F. Safonov // Russian Math. (Iz. VUZ). - 59. - 10. - 2015. - P. 1-15.

23 Bobodzhanov A.A. The method of normal forms for singularly perturbed systems of Fredholm integrodifferential equations with rapidly varying kernels / A.A. Bobodzhanov, V.F. Safonov // Sb. Math. 204. - 7. - 2013. - P. 979-1002.

24 Safonov V.F. Volterra integral equations with rapidly varying kernels and their asymptotic integration / V.F. Safonov, A.A. Bobodzhanov // Sb. Math. - 192. - 8. - 2001. - P. 1139-1164.

25 Safonov V.F. «Splashes» in Fredholm Integro-Differential Equations with Rapidly Varying Kernels / V.F. Safonov, A.A. Bobodzhanov // Math. Notes. - 85. - 2. - 2009. - P. 153-167.

26 Gantmakher F.R. Theory of matrices / F.R. Gantmakher. - Moscow: GITTL, 1953.

27 Konyaev Yu.A. On a method of studying some problems of the perturbation theory / Yu.A. Konyaev // Mathem. Coll. - 1993. - No. 12. - P. 133-144.

\author{
А.А. Бободжанов, Б.Т. Калимбетов, В.Ф. Сафонов
}

\title{
Оңтайлы жүйенің матрицасының спектрі ұдайы болған жағдайдағы басқарудың сингуляр ауытқымалы есебі
}

\begin{abstract}
Мақалада сапаның квадрат функционалы бар сингуляр ауытқымалы есебі қарастырылды. Мұндай есептер бұрын спектрдің белгілі шектеулерінде (оңтайлы жүйенің спектр нүктелері таза жорамал емес және жорамал оське қатысты симметриялы орналасса) Васильева-Бутузовтың шекаралық функциялар әдісі арқылы қарастырылған. Егер спектрдің нүктелерінің ең болмағанда біреуі тәуелсіз айнымалының кейбір мәндерінде жорамал оське түссе, шекаралық функциялар әдісі жұмыс істемейді.
\end{abstract}


Жұмыста спектрдің таза жорамал нүктелері бар жағдай зерттелді. Бұл жағдайда С.А. Ломовтың регуляризациялау әдісінің идеяларына негізделген басқа әдісті дамытуға тура келеді. Сондай-ақ бұрын қаралған басқару есептерінде шығындар функционалы кіші параметрге мүлдем тәуелді емес немесе кіші параметрге тегіс тәуелді болатыны байқалған. Бұл мақалада шығынның кіші параметрге регуляр емес тәуелділігі, яғни интеграл таңбасы астында экспоненциалды көбейткіш түрінде жылдам өзгеретін демпфирлеу функциясының бар болуы жағдайы қарастырылған. Осы жағдайда оңтайлы жүйе спектрінің беталысы демпфирлеу коэффициентіне байланысты болады, ол (белгілі бір жағдайларда) спектрді комплекс жазықтықтың қандай да бір жағына жылжытуы мүмкін. Онда спектрдің кейбір нүктелері жекеленген мәндерде (немесе тіпті кейбір континуалды жиындарда) тәуелсіз айнымалы таза жорамал болған жағдай туындауы мүмкін. Мұндай жағдайды жоғарыда аталған ВасильеваБутузовтың шекаралық функциялары әдісімен зерттеуге болмайды. Алайда қарастырылып отырған басқару есебін зерттеуге қатысты С.А. Ломовтың регуляризациялау әдісінің алгоритмін қолдану осы жұмыста толық қарастырылған. Бұл әдісті баяндау оңтайлы басқарудың классикалық есебі үшін Л.С. Понтрягиннің максимум принципін қысқаша сипаттаудан басталып, одан соң басқа идеялармен қатар, қарастырылып отырған басқару есебінің нәтижелерін негіздеу үшін қолданылды.

Kiлm сөздер: сингуляр ауытқу, Понтрягинның максимум принципі, регуляризация, асимптотикалық жинақтылық.

А.А. Бободжанов, Б.Т. Калимбетов, В.Ф. Сафонов

\section{Сингулярно возмущенные задачи управления в случае стабильности спектра матрицы оптимальной системы}

В статье рассмотрена сингулярно возмущенная задача управления с квадратичным функционалом качества. Такие задачи в их стандартной постановке при известных ограничениях на спектр (точки спектра оптимальной системы не являются чисто мнимыми и расположены симметрично относительно мнимой оси) были рассмотрены ранее с помощью метода пограничных функций ВасильевойБутузова. Если же хотя бы одна из точек спектра при некоторых значениях независимой переменной попадает на мнимую ось, метод погранфункций не работает. Именно такая ситуация с допущением чисто мнимых точек спектра исследована в настоящей работе. В этом случае приходится развивать другой подход, основанный на идеях метода регуляризации С.А. Ломова. Следует заметить также, что в рассмотренных ранее задачах управления функционал затрат либо вообще не зависел от малого параметра, либо допускал гладкую зависимость от параметра. В данной работе допущена нерегулярная зависимость от малого параметра, в частности, наличие в них быстро изменяющейся функции демпфирования в виде экспоненциально множителя под знаком интеграла. В этом случае поведение спектра оптимальной системы зависит от коэффициента демпфирования, который (при определенных условиях) может смещать спектр в ту или иную сторону в комплексной плоскости. При этом может возникнуть ситуация, когда некоторые точки спектра при отдельных значениях (или даже на некотором континуальном множестве) независимой переменной могут становиться чисто мнимыми. Эта ситуация не поддается исследованию упомянутым ранее методом пограничных функций ВасильевойБутузова. Однако его можно полностью изучить с помощью метода регуляризации С.А. Ломова, алгоритм которого применительно к рассматриваемой задаче управления развивается в настоящей работе. Изложение этого метода начинается с краткого описания принципа максимума Л.С. Понтрягина для классической задачи оптимального управления, который затем, наряду с другими идеями, применяется для обоснования результатов в рассматриваемой задаче управления.

Ключевые слова: сингулярное возмущение, принцип максимума Понтрягина, регуляризация, асимптотическая сходимость.

\section{References}

1 Lomov, S.A. (1981). Vvedenie v obshchuiu teoriiu sinhuliarnykh vozmushchenii [Introduction to the general theory of singular perturbations]. Moscow: Nauka [in Russian].

2 Reutenberg, J.N. (1971). Avtomaticheskoe upravlenie [Automatic control]. Moscow: Nauka [in Russian]. 
3 Boltyansky, I.G. (1964). Dostatochnye usloviia optimalnosti i obosnovaniia metoda dinamicheskoho prohrammirovaniia [Sufficient conditions for optimality and justification of the dynamic programming method]. Izvestiia Akademii nauk SSSR. Seriia Matematika - News of Academy of Sciences of the USSR, Mathematical series, 28, 3, 481-514 [in Russian].

4 Glizer, V.Ya., \& Dmitriev, M.G. (1975). Metod pohranichnoho sloia pri reshenii nekotoryikh zadach analiticheskoho proektirovaniia rehulyatora [The boundary layer method in solving some problems of analytical design of the regulator]. Tezisy dokladov Vsesoiuznoi konferentsii po asimptoticheskim metodam - Abstracts of the All-Union conf. by asymp. methods, Frunze: Ilim, 112-115 [in Russian].

5 Vasilyeva, A.B., \& Butuzov, V.F. (1987). Ob asimptotike resheniia tipa kontrastnoi struktury [On the asymptotics of a solution of the type of contrast structure]. Mathematicheskie zametki-Mathem. notes, 42, 6, 831-841 [in Russian].

6 Butuzov, V.F., Vasilyeva, A.B., \& Nefedov, N.N. (1977). Asimptoticheskaia teoriia kontrastnykh struktur [Asymptotic theory of contrast structures]. Avtomatika $i$ Telemekhanika - Avtomat. and Telemech., 7, 3-32 [in Russian].

7 Vasilyeva, A.B., Butuzov, V.F., \& Nefedov, N.N. (1998). Kontrastnye struktury v sinhuliarno vozmushchennykh zadachakh [Contrast structures in singularly perturbed problems]. Fundamentalnaiia $i$ prikladaiia mathematika - Fundament. and Appl. Math., 4(3), 799-851 [in Russian].

8 Lomov, S.A., \& Lomov, I.S. (2011). Osnovy matematicheskoi teorii pohranichnoho sloia [Foundations of mathemathical theory of boundary layer]. Moscow: Izdatelstvo Moskovskoho hosudarstvennoho universiteta [in Russian].

9 Lomov, S.A., \& Eliseev, A.G. (1986). Teoriia sinhuliarnykh vozmushchenii v sluchae spektralnykh osobennostei predelnoho operatora [The theory of singular perturbations in the case of spectral singularities of the limit operator]. Mathematicheskii sbornik - Math. collect., 131(173), 4(26), 544-557 [in Russian].

10 Bobodzhanov, A.A., Rashepkina, N.A., \& Safonov, V.F. (1998). Rehuliarizatsiia optimalnykh sinhuliarno vozmushchennykh sistem s bystro meniaiushcheisia dempfiruiushchei funktsiiei [Regularization of optimal singularly perturbed systems with a rapidly changing damping function]. Vestnik MEI - Vestnik MPEI, 6, 18-26 [in Russian].

11 Imanbaev, N.S., Kalimbetov, B.T., \& Temirbekov, M.A. (2013). Alhoritm metoda rehuliarizatsii dlia sinhuliarno vozmushchennoi zadachi s nestabilnym znacheniem yadra intehralnoho operatora [Algorithm the regularization method for a singularly perturbed problem with unstable value of kernel of the integral operator]. Vestnik Karahandinskoho universiteta. Matematicheskaia seriia - Vestnik of Karaganda University, Mathematics series, 4(72) , 64-70 [in Russian].

12 Kalimbetov, B.T., Yeskaraeva, B.I., \& Temirbekov, M.A. (2014). Matematicheskoe opisanie vnutrenneho pohranichnoho sloia dlia nelineinoi intehro-differentsialnoi sistemy [Mathematical description of the inner boundary layer for a nonlinear integro-differential system]. Vestnik Karahandinskoho universiteta. Seriia matematika - Vestnik of Karaganda University. Mathematics series, 3(75), 77-87 [in Russian].

13 Yeskaraeva, B.I., Kalimbetov, B.T., \& Temirbekov, M.A. (2014). Diskretnyi pohranichnyi sloi v sluchae nulevykh tochek spektra dlia sistem intehro-differentsialnykh uravnenii [Discrete boundary layer in the case of zero points of the spectrum for systems of integro-differential equations]. Vestnik Karahandinskoho universiteta. Seriia matematika - Vestnik of Karaganda University, Mathematics series, 75, 3, 88-95 [in Russian].

14 Kalimbetov, B.T., Yeskarayeva, B.I., \& Tolep A.S. (2015). Internal boundary layer for integral-differential equations with zero spectrum of the limit operator and rapidly changing kernel. Journal Applied Mathematical Sciences, 9, 141-144, 7149-7165.

15 Kalimbetov, B.T., Temirbekov, M.A., \& Habibullaev, Zh.O. (2012). Asymptotic solution of singular perturbed problems with an instable spectrum of the limiting operator. Journal Abstract and Applied Analysis, ID 120192.

16 Kalimbetov, B.T., Imanbaev, N.S., Sapakov, D.A., \& Tashimov, L.T. (2013). Regularized asymptotical solutions of integro-differential systems with spectral singularites. Journal Advances in Difference Equations, 109, doi: 10.1186/1687-1847-2013-109.

17 Safonov, V.F., \& Kalimbetov, B.T. (1995). A regularization method for systems with unstable spectral value of the kernel of the integral operator. Journal Differential Equations, 31(4), 647-656. 
18 Safonov, V.F., \& Bobodzhanov, A.A. (2017). Regularized asymptotic solutions of the initial problem of systems of integro-partial differential equations. Mathematical Notes, 102, 1, 22-30.

19 Safonov, V.F., \& Bobodzhanov, A.A. (2018). Regularized asymptotics of solutions to integro-differential partial differential equations with rapidly varying kernels. Ufimsk. Mat. Zh., 10, 2. 3-12.

20 Bobodzhanov, A.A., \& Safonov, V.F. (2018). A generalization of the regularization method to the singularly perturbed integro-differential equations with partial derivatives. Journal Russian Math. (Izvest. VUZ), 62, 3, 6-1\%.

21 Bobodzhanov, A.A., \& Safonov, V.F. (2016). A problem with inverse time for a singularly perturbed integro-differential equation with diagonal - of the kernel of high order. Journal Izvest. Math, 80, 2, 285-298.

22 Bobodzhanov, A.A., \& Safonov, V.F. (2015). Asymptotic solutions of Fredholm integro-differential equations with rapidly changing kernels and irreversible limit operator. Journal Russian Math. (Izvest. vuz), 59, 10, 1-15.

23 Bobodzhanov, A.A., \& Safonov, V.F. (2013). The method of normal forms for singularly perturbed systems of Fredholm integro-differential equations with rapidly varying kernels. Sibir. Math J., 204, 7, 979-1002.

24 Safonov, V.F., \& Bobodzhanov, A.A. (2001). Volterra integral equations with rapidly varying kernels and their asymptotic integration. Sibir. Math. J., 192, 8, 1139-1164.

25 Safonov, V.F., \& Bobodzhanov, A.A. (2009). «Splashes» in Fredholm integro-differential equations with rapidly varying kernels. Math. Notes, 85, 2. 153-16\%.

26 Gantmakher, F.R. (1953). Teoriia matrits [Theory of matrices]. Moscow: HITTL [in Russian].

27 Konyaev, Yu.A. (1993). On a method of studying some problems of the perturbation theory. Mathematicheskii sbornik - Mathem. collect., 12, 133-144 [in Russian]. 